\title{
Practice-based Approach \\ to Teaching University Students: \\ Trends in Foreign Didactics
}

\author{
Boris V. Tarev* \\ National Research University \\ Higher School of Economics \\ 20 Myasnitskaya Str., Moscow, 101000, Russia
}

Received 29.08.2015, received in revised form 15.09.2015, accepted 26.10.2015

The article deals with current trends in teaching University students by means of Practice-based approach. The approach that is based on practice is widely represented in contemporary Didactics in foreign countries because of the shift of educational priorities. The Practice-based approach is described from theoretical position. The author makes the wide presentation of Practice-based approach functions, as well as of educational practices that are recommended for application in practical training of University undergraduates. The paper lists the parameters of best educational practices that provide the efficiency of lifelong learning (LLL).

Keywords: practice-based approach, pedagogies, educational practices, professional practices, best educational practices.

DOI: 10.17516/1997-1370-2015-8-11-2684-2691.

Research area: pedagogy.

\section{Introduction}

The current social situation in Russia and abroad has caused an acute shortage of qualified practice-oriented specialists in the sectors of real economy. All this takes place with simultaneous growth of «professionals» with University diplomas. One of the reasons for the crisis of the traditional paradigm is the rapid obsolescence of information, which leads to the change in the key provision of Education from «the transfer of knowledge» to «education throughout life» (lifelong learning). Moreover, the labor market requires not the knowledge as such, but the ability of a specialist to acquire and apply it in practice, performing certain professional and social functions.

Of particular importance in training of a new generation of higher school graduates is given to Practice-based education, which is a rapidly developing trend in the system of higher education, being actively implemented in the educational programs of leading Universities in the world since the beginning of the 1990s. Its necessity was grounded in the «Agenda 21» at the 57th session of the UN General Assembly to declare ten years (2005-2014) The Decade

(C) Siberian Federal University. All rights reserved

* Corresponding author E-mail address: boristarev@mail.ru 
of Education for Sustainable Development (DESD), which is the process and the result of the prediction and formation of human qualities - knowledge, skills, attitudes, style of activity of individuals and communities, personality traits, competencies, providing a sustainable growth of living standards (Agenda, 1992).

The pioneers of Practice-based vocational training are medical and technical universities, which traditionally devote much time to the practical aspects of students training. They are the first to develop a problem-oriented training system, which has significantly increased the quality of future medical and engineering professionals. This was made possible thanks to the development and introduction of technologies of active and «blended» learning in educational programs of higher educational establishments. Currently, these processes penetrate into the system of higher business education.

Nowadays National educational initiatives provide an upgrade of the system of economic education. This includes the implementation of training strategies for graduates who are ready to be instantly involved in the processes of modernization of innovative economic development of Russia. This, for example, leads to invitation to economic higher schools of the professionals from real sectors of economy, such as finance, manufacturing, services, and so on. Thus, we develop Practice-based trend in the Russian economic and business education.

In the conditions of practice-based educational challenges special attention is to be paid to the analysis of the advanced foreign experience of innovative education, which accumulates information in the field of practicebased educational trends. If we have a look at the traditions of Practice-based approach in the system of higher education in foreign countries we can see that it has a pretty long history. The analysis of the current trends shows that the development of this approach has undergone the following path: from Active Learning (the 80-s of the XX century) to Cooperative Learning (the 90-s of the XX century), and further to Practice-based education (nowadays). The latter of these stages attracts great attention of Russian specialists in Didactics and Language teaching, researchers of national system of education, as it is consistent with the modern requirements to graduate's professional competencies, his ability to act in real conditions of working environment, to practically implement the acquired knowledge, skills, and competencies immediately after graduation from higher educational establishment. Particular importance is given to practical training in the process of professionally oriented teaching of foreign languages, with its priority to simulate the conditions for maximal implementation of the foreign language into real intercultural communication.

\section{Practice-based approach: key points}

This article focuses on the main vectors of interpretation of Practice-based approach (the approach, which is based on practice), proposed in the studies of foreign authors. We would like to understand the existing experience of analysis of language teaching and learning practices, evaluate it critically and to comprehend, according to what criteria this or that practice can be regarded as productive, best, adequate for implementation into the broad educational context of the system of the Russian higher education. The role of Practice-based approach can be regarded judging from the fact that nowadays foreign scholars actively began to develop methodology, theory, technology of the so-called Practice-Based Education Pedagogy (Higgs, 2011). The term Practice-Based Education focuses on education, in which students are being prepared to practice 
in a diverse range of activities, profiles, and professions. This training prepares students to ensure that they would become of high demand as members of society and private professional associations. The approach underlying the Practice-based methodology is education that meets the needs of graduates and practitioners, as well as all the stakeholders: clients, employers, and colleagues.

Practice-Based Education Pedagogy is based on its own terminological system in which a central place is occupied by the term «Practice» (Higgs, 2013). Practice is the goal, context, and environment for practically oriented education. At the same time this approach is implemented in various forms: in the form of games, hybrid activities, distance learning, in the classroom, and so on. It is important that the focus on practice is fixed in the curriculum, which reflects all of these kinds of activities. Along with formal education, practical orientation is realized on the informal and non-formal levels of the educational system.

The theoretical basis of Practice-based approach is grounded on the following foundations:

- is situated within practice-relevant contexts

- involves reflexivity, participation and dialogue

- occurs in many communities of practice (including workplace, academic, multidisciplinary communities)

- involves a process of socialization into professional/occupational worlds, roles, identities and career paths

- involves engagement, through industry partnerships, in practice-based teaching and learning activities

- develops capabilities and behaviors that will enable graduates to contribute to local communities and society as responsible citizens and professionals who display ethical conduct and duty of care (Higgs 2012).

Practice-based approach meets the requirements of social order. In studies (Higgs, 2011, 2012, 2013) the following aspects of the social importance of educational practices are highlighted:

- Pedagogical: the approach is aimed at the description of the process of focused training (through education) of the younger generation for social, professional practice,

- Goal: the approach is aimed at achieving the goals related to the development of relevant for working activity social, technical and professional abilities of students as well as formation of their perceptions of their working identity, maintaining their development as valuable for global community active («positive») citizens,

- Context: the approach is mandatory implemented in such contexts, which correspond to the interests and needs of students, teachers; it includes opportunities for practically oriented models both while university education and at working and social activities. To the creation of these contexts should contribute both the planned educational conditions (formal education) - the curriculum, resources, methods and techniques, and unplanned, non-system conditions (nonformal education),

- Reflexive: students' activities must be constantly assessed, and, primarily, by themselves. This enables the creation of a clear system of coordinates, which is reflected in the educational documentation and educational activities,

- Socialization: through pedagogical practices students have the opportunity to acquire professional socialization, to enter the professional community and get acquainted with its practices, 
- Social involvement: in the structure of the approach practices and pedagogical theory are characterized by having close relationships (links). These relationships arise in the process of interaction between student and teacher, instructor and trainees, between learners (collaborative learning), university professors and practitioners, universities and legislative bodies, professional groups and communities,

- Authenticity and relevance: authenticity and relevance are the constituent elements of the educational goals, educational activities, students' knowledge assessment, and evaluation of the curriculum of Practice-based education. Teaching methods, including the behavior of teachers must meet the expectations, norms, knowledge and practice of the profession being studied,

- Normativity (compliance with standards, values, and ethical norms): all aspects of the curriculum and teaching activities must meet the standards. These standards are set in accordance with practical requirements and professionalism, with standards of professional conduct and the standards adopted by the industry being components of practical activity and professional socialization. These standards should «permeate» the teaching process over all subjects in the educational process for students of higher educational institution.

\section{The impact of educational practices}

From the point of view of the technological constituents Practice-based approach is grounded on the use of various educational practices, which allow to realize all socially significant opportunities of education that is based on this approach. The term «practice» is related to the social, namely, professional practice. The term «practices» characterizes the professional activity. It can also refer to a specifically chosen method of implementation of practical and / or professional activities. The term «professional practices» reflects ethics, relevant professional standards, implementation of the communication at the level of «trainee - client», the interdisciplinary nature of the activity.

In the opinion of researchers practice can be:

- collective (e.g., a profession's practice): it involves regulated, social interaction, discussions, adoption of common decisions. It can be attributed to determining of the identity, «practical philosophy», «norms of practical culture», ethical standards, the rules of social behavior,

- individual (e.g., the individual practice of a particular person - an individual practitioner's practice): it involves individual practical models of behavior, combined with the practical models of the community and at the same time based on the interests, experiences, preferences, plans, values of the individual. A trainee acquires and converts the collective experience, sifts it through his own models of behavior (Higgs, 2011).

In foreign literature, educational practices (open educational practices, best education practice) are refered to as «the wide range of individual activities, policies, and programmatic approaches to achieve positive changes in student attitudes or academic behaviors» (Arendale, 2015). Educational practices in foreign interpretation are as close as possible to the pragmatic (Practice-based) approach suitable for their understanding and evaluation. This conclusion is supported by the proposed classification of educational practices. They are divided into:

- Promising education practice: this category includes the practices that are described 
in detail in terms of content and conditions of implementation, relying on a serious theoretical foundation, but not tested in the general practice,

- Validated education practice: this includes those practices from the category of promising education practice, which were implemented, and the success of which has been confirmed by both the objective results and subjective assessments,

- Exemplary education practice: this category includes those practices which repeatedly confirmed their positive effect in the variety of educational contexts andare consistently positively evaluated by the participants of the process (the term «exemplary education practice» is used in the US documentation - Federal Department of Education) (Arendale, 2015).

The structure of the Practice-based approach has the following key strategic educational practices (identified after the conducted analysis of (Higgs, 2011, 2012, 2013):

1) Supervised workplace learning: this educational process includes teaching students at the workplace under the formal or informal guidance from the instructor or an experienced professional. An example would be the training of teachers. Educators or professionals act as mentors (tutors) or demonstrators,

2) Independent workplace learning and experience: while training in some areas there is no opportunity or tradition of working with an instructor. In such cases, students can comprehend the experience on their own, developing their own educational programs. Some curricula enable students to work in the production on a fee basis and at the same time acquire the relevant skills and experience,

3) Simulated workplaces: Universities can organize the creation of real jobs or simulations where students will be able to provide services to their customers. An example is the work of the broadcasting stations and restaurants that serve the campus and allow students to gain real work experience,

4) Simulated practice-based learning: practical activities can be simulated by creating a practical environment, e-learning programs (with an emphasis on case studies and problem solving), practical exercises, role plays, peer learning, debates,

5) Distance and flexible practice-based learning: most of Practice-based education is carried out in the form of distance learning by means of flexible and distributed pedagogies. These forms are used to create comfortable environment for the students. This trend is particularly relevant in the post-graduate education for mature age students, for design and implementation of international education programs,

6) Peer learning: joint training contributes to the definition of professional aptitudes, abilities, and knowledge in the process of contact with other students and limited interaction with the teachers. Such training can take place in the conditions of distance learning, flexible and e-learning (for example, the implementation of student projects) through Skype or other means of communication. The grade given by the other students has developing and positively critique importance,

7) Independent learning: experts in many areas must rely on themselves when they make certain judgments, opinions, criticisms. Practicebased education may contain elements of selfassessment training, autonomy in the choice of educational technologies, reflection and selfdevelopment,

8) Blended learning: no single educational approach can meet all the requirements of the students in their strive for realization of their educational goals and objectives. Blended learning is trying to respond to these challenges, and combine traditional pedagogy with innovative 
approaches in teaching students both within the University and outside it, individually or in groups, by means of real, theoretical or simulation approaches.

In addition to the strategically significant educational practices that in general guide practice-based parameters of the learning process, researchers identify tactical educational practices that make up the special cases of strategic practices and ensure the implementation of the latter in the training of students. The analysis of studies (Arendale, 2015, Drummond, 1995, Grave, 2015) revealed the parameters of tactical productive educational practices. These include the following indicators:

- good practice promotes interaction between teacher and student,

- good practice promotes interaction between students,

- good practice provides active learning technologies,

- good practice provides feedback,

- good practice teaches to time management,

- good practice sets high goals,

- good practice provides diversification use of talent, experience and ability to learn.

Tactical educational practices are a set of effective tools and situations, which a teacher can use to improve the educational process. Below we give examples that summarize the most interesting practices with significant optimizing potential.

Practices for blended online learning: regular and frequent online contact with students, daily revision and participation with comments in forums, effective feedback, reasonable time management.

Practices for lecturing: rhetorical questions, express poll of students' opinion, team questionanswer work, explanation with demonstration of logic, «delayed» record of what has been heard followed by a discussion in small groups, express testing, inclusion of interesting stories in the context of the lecture.

Practices for work at practical class: group discussion, sharing of personal experiences, individual self-study followed by discussion, testing with self-assessment, case-method, discussion of video material, role plays.

Assessment practices: no direct praise, description of success of student's learning activity, non-verbal assessment.

Practices for adapting first-year students to academic activities: diversification of training activities, design of classroom, interaction with students in real life, in social media (networks), presentation of algorithm of course design, demonstration to students of various interests of teachers and their qualifications, inspire the ability to think carefully and reflexively, use of interdisciplinary lectures by several teachers, demonstration of team work of the teaching staff, design of the course in collaboration with students, development of self-assessment competencies.

Practices of presentation of new information: on the basis of a spiral progression, presentation of heuristic approach, the presentation through problem solving, presentation by the method of «trial and error», presentation through independent - and joint learning, presentation through simulation and modeling of real conditions.

\section{Conclusion}

The analysis of trends of research in the sphere of Practice-based approach that is actively developed in foreign pedagogical literature shows that their attention is focused on higher education. This is the system of University education, in which most attention is given to practical activities of students, 
mostly connected to real professional reality where they will have to occur after graduation. The emphasis on practice, highlighting its importance is fully consistent with the modern educational competence paradigm, aimed at preparing graduates for practical actions, for application of the acquired knowledge, skills, and competencies in professional reality.

The research of the developed abroad Practice-based approach has an important pragmatic significance for Russian scientists, who are interested in implementation of the competence approach into the system of higher education. They consider that it is necessary to change the predominantly traditional explicitly theoretical educational system, which has not much to do with practical solutions and realization. We need a critical analysis of the proposed educational practices, development of adequate conditions for optimal extrapolation of productive practices in the Russian educational context.

\section{References}

Agenda 21 (1992), Available at: http://www.un.org/ru/documents/ decl_conv/conventions/ agenda21.shtml (accessed 15 July 2015).

Arendale, D. (2015) What is a Best Education Practice? Available at: http://www. besteducationpractices.org/what-is-a-best-practice.

Drummond, T. (1995) A Brief Summary of the Best Practices in College Teaching, Available at: http://teaching.uncc.edu/learning-resources/articles-books/best-practice/instructional-methods/bestpractices-summary, (accessed 15 July 2015).

Grave, G. (2015) Pédagogie: pratiques efficaces et théories pédagogiques [Pedagogy: Effective Practices and Pedagogical Theories], Available at: https://zestedesavoir.com/tutoriels/262/les-pratiquespedagogiques-efficaces, (accessed 15 July 2015).

Higgs, J., Barnett, R., Billett, S., Hutchings, M. \& Trede F. (Eds.) Practice-Based Education: Perspectives and Strategies. Rotterdam, Sense Publishers, 2012. 37 p.

Higgs, J. Practice-based education: Enhancing practice and pedagogy. Final Report for ALTC Teaching Fellowship. Australian Learning and Teaching Council, Australia, 2011. 289 p.

Higgs, J., Sheehan, D., Currens, J.B., Letts, W. \& Jensen, G.M. Realising Exemplary PracticeBased Education. Rotterdam, Boston, Taipei, 2013. 316 p. 


\title{
Зарубежные тенденции
}

\section{в практикоориентированной \\ подготовке студентов}

\author{
Б.B. Тарев \\ Научно-исследовательский университет \\ Высшая школа экономики \\ Россия, 101000, Москва, ул. Мясницкая, 20
}

\begin{abstract}
В статье речь идет о современных тенденииях в подготовке студентов вузов, основанных на практикоориентированном подходе к высшему профессиональному образованию. Подход, основанный на практике, широко исследуется в современной зарубежной педагогике и дидактике в связи со сменой образовательных приоритетов. В статье практикоориентированный подход описывается с позиции теоретического представления. Делается краткий экскурс в историю возникновения данного подхода. Широко представлены функиии практикоориентированного подхода, а также образовательные практики, рекомендуемые $к$ использованию для обеспечения практической направленности прочесса подготовки современных выпускников вузов. Описываются параметры передовых образовательных практик, использование которых обеспечивает эффективность LLL.

Ключевые слова: практикоориентированный подход, практика, образовательные практики, педагогические технологии, профессиональные практики, передовые образовательные практики.
\end{abstract}

Научная спеииальность: 13.00.00 - педагогические науки. 